\title{
Detection and identification of blood-borne infections in dogs in Nigeria using light microscopy and the polymerase chain reaction
}

\author{
Anise N. Happi ${ }^{a,{ }^{,}}$, Angela J. Toepp ${ }^{b}$, C.A. Ugwu ${ }^{a}$, Christine A. Petersen ${ }^{b}$, and Jane E. \\ Sykes $^{\mathrm{C}}$ \\ aDepartment of Veterinary Pathology, University of Ibadan, Ibadan, Nigeria \\ ${ }^{b}$ College of Public Health, Center for Emerging Infectious Diseases, University of lowa, lowa City, \\ lowa, USA \\ 'Department of Medicine and Epidemiology, School of Veterinary Medicine, University of \\ California-Davis, Davis, CA, USA
}

\begin{abstract}
Many sick dogs brought to the University of Ibadan Veterinary Teaching Hospital (UIVTH) are infested with ticks and are anemic. Up until recently, light microscopy (LM) has been the only available means used for detection of blood-borne infections. In other parts of the world, PCRbased assays been used as a gold standard for accurate diagnosis of blood-borne infections.

In this study, we used LM and broad-spectrum rRNA gene PCR-based assays on 116 blood samples from dogs brought to the UIVTH for detection of the 18S rRNA gene of Babesia and the 16S rRNA genes of Ehrlichia and hemotropic mycoplasmas. The relationship between clinicopathological findings and PCR results was evaluated. Age, sex, presence of ticks, anemia, co-infection status, and fever were also assessed in relation to PCR positivity to determine the risk factors using stepwise logistic regression analyses.

Light microscopic examination revealed an overall prevalence of infection of 14.7\% (17/116). Organisms detected were Babesia canis (3.5\%), Ehrlichia canis (10.3\%) and Trypanosoma congolense $(0.9 \%)$ and a single coinfection with Babesia canis and Ehrlichia canis $(0.9 \%)$. PCR analysis revealed 89/116 (76.7\%) positive samples. Infections with 1, 2 and 3 infectious agents occurred in $49(55.1 \%), 36(40.4 \%)$ and $4(4.5 \%)$ samples, respectively. Specifically, among the 89 PCR positive samples, Babesia spp. (85.4\%) was the most abundant infection followed by Ehrlichia spp. (46.1\%) and hemoplasmas (13.5\%). Sequencing of PCR products identified two samples (1.7\%) that contained Hepatozoon canis DNA. Sequencing of hemoplasma positive samples identified 'Candidatus Mycoplasma haemobos' in $0.8 \%$ of dogs. Using PCR, a 5-fold higher prevalence of blood-borne infections was found in the dogs $(76.7 \%, 89 / 116)$ than with LM $(14.7 \%, 17 / 116)$ alone"
\end{abstract}

\footnotetext{
*Corresponding author: anisehappi@yahoo.com (A.N. Happi).

Conflict of interest statement

The authors have no competing interests.
} 
Dogs between 1 and 12 months were the most frequently infected with multiple agents (47.2\% double and 50.0\% triple infections). Male dogs had the highest prevalence of infection (80.4\%) and more triple infections (75.0\%). A total of 57.3\% of infected dogs were anemic. Anemic dogs were 2.77 times more likely to test positive for Ehrlichia spp. (OR: $2.7795 \%$ CI: 1.25-6.16) and dogs with ticks were 3.6 times more likely to test positive for hemoplasmas (OR $=3.6095 \% \mathrm{CI}$ : $1.05-12.38)$.

This study underscores the abundance of blood-borne infections in dogs in Ibadan, Nigeria, which is underestimated using light microscopy. This is also the first evidence of existence of 'Candidatus Mycoplasma haemobos' in a dog in Nigeria and in Africa. Consequently there is a need for molecular diagnostic facilities for routine screening of sick animals, as multiple infections were not found by light microscopy.

\section{Keywords}

Mycoplasma haemobos; Blood-borne pathogen; Molecular diagnosis; Africa; Dog

\section{Introduction}

Infections with blood-borne pathogens are common in dogs and can be associated with high morbidity and mortality. In Nigeria the main blood-borne pathogens in dogs are Babesia spp., Ehrlichia spp., Hepatozoon canis, Theileria spp., and Trypanosoma spp. (Adamu et al., 2014; Happi and Anita, 2012; Kamani et al., 2013; Useh et al., 2003). These organisms can cause anemia, weight loss, and other clinical signs in dogs, and some are of zoonotic importance (Otranto et al., 2009).

While some infections result in overt clinical signs, others are subclinical (Hii et al., 2012). In most cases, the identification of anemia results in consideration of a blood-borne infection as a possibly underlying cause. In Nigeria, diagnosis is usually based on physical examination and microscopic detection of the pathogen in peripheral blood, and rarely by molecular methods. This approach is insensitive and lacks specificity. With globalization, climate change, and increased movement of humans and animals across the continent, there is an additional challenge of introduction and re-emergence of new blood-stream pathogens in West Africa (Kamani et al., 2013). To better understand the epidemiology of blood-borne infectious agents in dogs in Africa, there is need to employ more robust, sensitive and rapid diagnostic assays such as PCR.

Several epidemiological surveys for blood-borne pathogens have been carried out on dogs in Nigeria but very few of them utilized molecular tools (Kamani et al., 2013; Ogo et al., 2012; Suksawat et al., 2001). These studies were focused on the most common pathogens such as Babesia spp., Trypanosoma spp., and less so on Hepatozoon and Ehrlichia and very few on hemotropic mycoplasmas.

The objective of this study was to determine the identity and prevalence of blood-borne organisms of dogs in southwestern Nigeria using molecular tools. In addition, risk factors for these pathogens were assessed to aid diagnosis of these infections in the future. 


\section{Materials and methods}

\subsection{Study area and animals}

The study was carried out on dogs evaluated for illness at University of Ibadan Veterinary Teaching Hospital (UIVTH), University of Ibadan, Nigeria. A total of 116 dogs of various breeds and ages ( 2 days-16 - years) seen between April and August 2013 were enrolled in the study. Signalment, clinical history and physical examination were available. Thirty-nine dogs were clinically suspected to be infected with blood-borne pathogens based on the presence of fever, icterus, tick infestation, or anemia.

\subsection{Light microscopy (LM) examination of blood from UIVTH dogs}

Blood samples were collected into EDTA tubes for complete blood count and LM screening for infectious agents. Hematological analysis was done as described elsewhere (Schalm et al., 1975; Jain, 1986). The PCV was determined using the microhaematocrit method (Jain, 1986). Hemoglobin concentration was determined using the cyanmethe-moglobin method (Jain, 1986). The platelet and WBC counts were determined using a improved Hawksley hemocytometer with premade diluents (Jain, 1986), while the differential leukocyte count was determined by counting from a total of 200 leukocyte cells from randomly selected fields. The leukocytes were classified into types, and the relative and absolute leukocyte values of each type were calculated (Schalm et al., 1975).

From each EDTA blood sampled, $500 \mu \mathrm{l}$ were aliquoted into another tube and kept at $-20{ }^{\circ} \mathrm{C}$ for DNA extraction. Whole blood and buffy coat smears from each dog were made, air-dried and stained using Giemsa stain and examined by a veterinary clinical pathologist ( $\mathrm{AH})$ under LM at $\times 100$ oil immersion for blood-borne microbes, including visible intraerythrocytic piroplasmas, intracytoplasmic morulae consistent with rickettsial organisms, Hepatozoon gamonts, or epierythrocytic bacteria (hemoplasmas). The criteria for LM identification of each of the organism were based on the morphological characteristics described by Harvey (2001).

\subsection{DNA extraction}

DNA was extracted from $200 \mu$ of EDTA blood using the DNeasy blood and tissue kit (Qiagen LTD, USA) according to the manufacturer's protocol. The DNA was eluted with $100 \mathrm{ul}$ elution buffer and kept at $-20{ }^{\circ} \mathrm{C}$ for PCR and sequencing. All DNA extraction was performed at the Africa Center of Excellence for Genomics of Infectious Diseases (ACEGID) laboratory, Redeemer' University, Ede, Nigeria.

\subsection{Polymerase chain reaction and sequencing of amplified DNA products}

Extracted DNA was used as template in a standard PCR assay using primers for detection of the 16S rRNA gene of hemotropic Mycoplasma spp. (Jensen et al., 2001), 18S rRNA gene of Babesia spp. (Sikorski et al., 2010), and the 16S rRNA gene of Ehrlichia spp. and Anaplasma spp. (Lappin et al., 2004). PCR amplification was performed as previously described (Sykes et al., 2005). Ultrapure water was used as a negative control. 
The resulting PCR products were sequenced to confirm their identity as previously reported (Sykes et al., 2005). DNA sequencing was performed using automated methods (California University DNA Sequencing Facility, Davis, CA, USA). Sequences obtained were compared with those in the GenBank database using Basic Local Search Alignment Tools (www.ncbi.nlm.gov/BLAST).

\subsection{Statistical analysis}

Descriptive statistics were used to determine the infection rate in sampled dogs and to describe other factors associated with infection in dogs. Chi-squared analyses were performed to determine whether there were significant differences in the number of dogs infected based on age and sex. For this purpose, dogs were divided in 4 age groups of 0-12 months ( 43 dogs), > 1-2 years ( 19 dogs), $>2-5$ years ( 44 dogs) and the group of 7 years ( 4 dogs) and a group of 6 dogs with no record of age. Stepwise logistic regression analyses were performed to determine the effects of several demographic and clinical variables on PCR positivity. All analyses were completed at the 0.05 significance level. Graphical and logistic regression analyses were completed using Excel (Microsoft, Redmond, WA), SAS (SAS Institute, Cary, NC), and GraphPad Prism 7 (La Jolla, CA).

\section{Results}

\subsection{Distribution of sampled dogs}

Of the 116 dogs, 43 were 1 year-old or younger, 23 were > $1-2$ years, 33 were $>2-5$ years, 6 were $>5-7$ years, 4 were above 7 years of age, and 7 had unknown age. Sixty- seven dogs were females while 46 were males and 3 had no record of their sex. All of the dogs were ill dogs owned by individual households located in the vicinity of the teaching hospital.

\subsection{Detection of blood-borne microorganisms by light microscopy}

Of the 116 dog blood samples, 17 (14.7\%) contained blood-borne microorganisms as identified using LM. Among these positive samples, Ehrlichia canis was the most abundant (12/17, 70.6\%), followed by Babesia canis $(4 / 17,23.5 \%)$ and Trypanosoma congolense $(1 / 17,5.9 \%)$ (Fig. 1). The overall prevalence of infection was $10.3 \%$ for E. canis, $3.5 \%$ for B. canis, and $0.9 \%$ for T. congolense (Table 1).

\subsection{Detection of blood-borne microorganisms by PCR and sequence analysis}

Using PCR, a 5-fold higher prevalence of infection with blood-borne microorganisms was found in the dogs $(76.7 \%, 89 / 116)$ than with LM alone. Blood-borne microorganisms identified using PCR were Babesia spp. (85.4\%, 76/86 samples), Ehrlichia spp. (47.2\%, $42 / 89$ samples), and hemotropic mycoplasmas. (13.5\%, 12/89 samples). The presence of Ehrlichia and Babesia in samples positive by LM was confirmed in all of these samples using PCR. Sequencing and analysis of PCR products revealed that all Babesia and Ehrlichia positive samples were $B$. canis and E. canis respectively. Most (11/12) hemotropic mycoplasmas were Mycoplasma haemocanis. 
Using broad-spectrum rRNA gene PCR and sequencing, two additional blood-borne agents were identified in 3 samples. 'Candidatus Mycoplasma haemobos' was identified from a hemoplasma-positive sample, and Hepatozoon canis was identified in two samples (Table 1).

Comparison between LM and molecular diagnoses revealed more microorganism species (n $=5)$ and more positive samples $(n=89)$ detected by PCR and sequence analysis than with $\mathrm{LM}$ ( $\mathrm{n}=3$ and $\mathrm{n}=17$, respectively) (Fig. 2). Of all the samples examined, only $3.5 \%$ Babesia canis infections were identified using LM compared to $65.5 \%$ via PCR. The prevalence of Ehrlichia canis infection in dogs by LM was $10.3 \%$ compared with $36.2 \%$ by PCR (Table 1). In addition, no hemoplasma infection was identified by LM compared to a prevalence of $10.3 \%$ by PCR.

With the combined use of LM and PCR, 89 (76.7\%) samples were positive for blood-borne microorganisms (B. canis, E. canis, M. haemocanis, H. canis, T. congolense and 'Candidatus M. haemobos'). Single infections occurred in $49(55.1 \%)$ dogs, while mixed infections with 2 different organisms were found in $36(40.4 \%)$ dogs and 3 pathogens in $4(4.5 \%)$ dogs (Table 2). Among single infections, B. canis was the most prevalent (75.5\%) followed by E. canis (18.4\%) and M. haemocanis (6.1\%) (Table 2). When 2 microorganism species were present, $B$. canis and $E$. canis was the most frequent co-infection $(80.6 \%, 29)$ followed by $B$. canis and $M$. haemocanis $(11.1 \%, 4)$ (Table 2). Samples that contained 3 different microorganisms were B. canis, E. canis and M. haemocanis (3 dogs) and B. canis, M. haemocanis, and $H$. canis $(1 \mathrm{dog})$.

Among the 38 dogs that were clinically suspected to be infected with blood-borne pathogens, 7 (18.4\%) and 31 (81.6\%) were found to be positive by LM and PCR, respectively.

\subsection{Risk factors for infection with blood-borne microorganisms}

The prevalence of infection with blood-borne microorganisms was higher in dogs aged between 0 and 12 months $(81.4 \%)$ and $>2-5$ years $(75.8 \%)$. Dogs aged $>5-7$ and $>7$ years had a lower prevalence of infection (50.0\%) and represented 5.7\% of infected animals (Table 3). However, there was no significant difference in the prevalence of infection among age groups or between male and female dogs.

Eighteen percent (18.0\%; 21 dogs) of dogs had observed ticks out of which $76.2 \%$ (16) tested positive for blood-borne microorganisms. All dogs that had ticks and fever tested positive and represented 7.9\% of infected dogs (Table 3). However, $67.4 \%$ (60) of infected dogs had no reported tick infestation. In addition, all dogs with fever tested positive for blood-borne microorganisms but represented only $6.7 \%$ of positive dogs (Table 3 ).

\subsection{Hematological findings associated with blood-borne infections in Nigerian dogs}

Abnormal hematological findings recorded in infected dogs were thrombocytopenia (63 dogs), anemia (51 dogs), leukopenia (32 dogs), panleukopenia (1 dog) and leukocytosis (1 dog). Sixty-one dogs were anemic (PCV < 35\%) of which $51(83.9 \%)$ tested positive, representing $57.3 \%$ of infected dogs (Table 3). Anemic dogs also had more single, double and triple infections $(46.9 \%, 69.4 \%$ and $75 \%$, respectively, Table 3$)$ compared to non- 
anemic dogs. However, among the 54 dogs that had a PCV within reference intervals, 37 $(68.5 \%)$ tested positive, $53.1 \%$ of which had only a single infection identified (Table 3 ). Thrombocytopenia was particularly prevalent among B. canis-infected dogs (Table 4). Anemia was the most common finding in E. canis-infected dogs (66.7\%). The dog with pancytopenia was infected with $E$. canis. The dog with leukocytosis had a mixed infection with B. canis and E. canis.

\subsection{Logistic regression analysis}

To further analyze whether clinical or demographic variables were risk factors for testing positive via PCR for Babesia spp., Ehrlichia spp., or Mycoplasma spp., logistic regression models were created using stepwise elimination. Three models were created one for Ehrlichia spp., Babesia spp., and Mycoplasma spp. infections. The following variables were assessed: sex, age, anemia status, presence of ticks, thrombocytopenia, leukopenia, neutropenia, co-infection with mycoplasma, co-infection with Ehrlichia, and co-infection with Babesia spp., respectively. No variables were identified to be significant risk factors for testing positive via PCR for Babesia spp. (Table 5). When controlling for all other variables, dogs that were anemic were 2.77 times more likely to test positive for Ehrlichia spp. (OR: 2.77 95\% CI: 1.25-6.16). Dogs with ticks found on physical examination were 3.6 times more likely to test positive for hemoplasmas. ( $\mathrm{OR}=3.6095 \%$ CI: $1.05-12.38)$ (Table 5).

\section{Discussion}

The results of this study suggest that most dogs brought to the UIVTH in Ibadan, Nigeria, are exposed to tick-borne organisms and the use of LM and clinical examinations underdiagnosed the prevalence of these infections. Molecular evidence of a hemoplasma ('Candidatus M. haemobos') previously reported in Asia and Europe in cattle and in northern Australian dogs was also demonstrated in a dog in Ibadan.

The overall prevalence of infection with blood-borne infections recorded in UIVTH during this study (76.7\%) was higher than reported in previous studies of dogs in Europe, Asia, and America. However, this is similar to the findings from other studies in Praia, Cape Verde, (Gotsch et al., 2009), Plateau, Rivers and Kwara States in Nigeria using PCR (Kamani et al., 2013). Most other studies of blood-borne pathogens in dogs and other animals in Nigeria have been based on microscopy (Akande et al., 2010; Okeke et al., 2013; Okubanjo et al., 2013). The prevalence of infection was higher when molecular diagnosis was used (76.7\%) compared to tentative clinical diagnosis (33.6\%) and light microscopy (14.7\%), and molecular diagnosis allowed identification of the specific agent present. However, the true prevalence of infection may be even higher, because although PCR is highly sensitive, adult dogs may also suppress the presence of organisms in blood to a level that is not even readily detected by PCR amplification.

The five genera detected by LM and PCR (Babesia, Ehrlichia, Hepatozoon, Mycoplasma and Trypanosoma) have been reported previously in Nigeria: B. canis (Irwin, 2009; Zahler et al., 1998), Hepatozoon canis (Aydin, 2014; Ezeokoli et al., 1983; Happi and Anita, 2012; Okubanjo et al., 2013; Sasaki et al., 2008), E. canis (Adamu et al., 2012; Kamani et al., 2013), Trypanosoma spp. (Tono et al., 2015), M. haemocanis and 'Candidatus Mycoplasma 
haematoparvum' (Aquino et al., 2016). However, molecular evidence of 'Candidatus M. haemobos' has only been reported in Asia, America and Europe in cattle (Ayling et al., 2012; Girotto et al., 2012; Hoelzle et al., 2011; McFadden et al., 2016; Meli et al., 2010; Tagawa et al., 2008) and in dogs from northern Australia (Hii et al., 2012). The clinical significance of this organism in dogs remains to be determined.

Co-infections with multiple blood-borne agents were also detected in the study reported here, as in other studies (Hii et al., 2012; Maggi et al., 2013; Nwoha et al., 2013). The infection rate was high (81.4\%) in dogs between the ages of 0-12 months. Although not significant $(p>0.05)$ compared to other age groups, a higher prevalence of infection with blood-borne organisms in dogs less than a year of age when compared with adult dogs has been noted in other studies (Konto et al., 2014; Okubanjo et al., 2013; Penzhorn, 2011). However, Tsegay et al., 2016 documented a higher prevalence of infection in adult dogs (33.7\%), followed by geriatric dogs (29.3\%), then puppies (24.6\%) in Ethiopia (Tsegay et al., 2016). The high prevalence of blood-borne infections in young dogs might reflect their immature immunity and gregariousness. This is likely to increase their chances of contact with vectors when compared with adult and senior dogs, which may be less likely to roam.

We recorded that 56 (67.4\%) infected dogs had no report of tick infestation. Our findings underscore the fact that an absence of ticks on dogs does not exclude blood-borne infections. However, $100 \%$ of dogs with fever and ticks tested positive, suggesting that dogs in this category are highly likely to be infected. Of interest, there was a significant association between the finding of ticks and positive PCR results for hemoplasmas. This suggests that a clinical picture that includes tick infestation, even in the absence of identification of organisms via light microscopy, should strongly suggest hemoplasma infection in dogs in Ibadan. It also provides additional epidemiological evidence that ticks may be vectors for hemoplasma infections in dogs, which has not yet been clearly established.

Thrombocytopenia was the most common hematological alteration in infected dogs. Bourdoiseau, 2006 and Solano-Gallego et al., 2008 described classical clinicopathological findings in dogs with acute blood-borne infections (primarily Babesia spp. infections) that included thrombocytopenia, febrile syndrome (fever, anorexia, depression, dehydration) and hemolytic syndrome (anemia, bilirubinuria, hemolysis) (Bourdoiseau, 2006; Solano-Gallego et al., 2008). Similarly, Caprariis et al. identified thrombocytopenia as the most frequent abnormal hematological finding among young dogs infected by vector-borne pathogens including A. platys, B. vogeli and in dogs co-infected with A. platys and B. vogeli or A. platys and Bartonella spp. (de Caprariis et al., 2011). In contrast, Nalubamba et al. (2015) found anemia (96.4\%) to be the most consistent hematological abnormality in dogs infected with Babesia spp. In the study reported here, the anemic dogs were 2.77 times more likely to test positive for E. canis. It is possible that this may reflect the presence of the advanced or chronic stage of canine monocytic ehrlichiosis present in most Nigerian dogs when they are brought to the veterinary clinic for treatment.

This is the first report of 'Candidatus M. haemobos' in a dog from Africa, and the second report worldwide. Co-infections with multiple blood-borne microorganisms in dogs are common in Ibadan. In the future, molecular diagnostics should be employed for routine 
diagnosis of blood-borne infections, as an accurate diagnosis could not be made based on clinical or light microscopic or hematological findings. In addition, these findings underscore the need to recommend tick prevention methods to clients that own dogs in Nigeria, This should include the use of reliable acaricidal products even in the absence of observed infestations, which in the authors' observations is not wide-spread.

\section{Acknowledgments}

The authors would like to thank Prof. Christian T. Happi, Director of the Africa Center of Excellence for Genomics of Infectious Diseases), Redeemers University, Osun State, Nigeria for providing lab space for this study. The authors would also like to acknowledge LeAnn L. Lindsay for providing technical support to perform the PCR amplification and sequencing.

Funding

This work was self-funded.

\section{Abbreviations:}

PCR

polymerase chain reaction

LM

light microscopy

UIVTH

University of Ibadan Veterinary Teaching Hospital

\section{References}

Adamu NB, Adamu JY, Salisu L, 2012 Prevalence of ecto-, endo- and haemoparasites in slaughtered dogsin Maiduguri, Nigeria. Rev. Med. Vet-Toulouse 163, 178-182.

Adamu M, Troskie M, Oshadu DO, Malatji DP, Penzhorn BL, Matjila PT, 2014 Occurrence of ticktransmitted pathogens in dogs in Jos, Plateau State, Nigeria. Parasite Vector 7.

Akande FA, Takeet MI, Makanju OA, 2010 Haemoparasites of cattle in Abeokuta, South West Nigeria. Sci. World J 5, 19-21.

Aquino LC, Kamani J, Haruna AM, Paludo GR, Hicks CA, Helps CR, Tasker S, 2016 Analysis of risk factors and prevalence of haemoplasma infection in dogs. Vet. Parasitol 221, 111-117. [PubMed: 27084481]

Aydin MF, 2014 Hepatozoon species infections in Nigeria. Sokoto J. Vet. Sci 12, 61-62.

Ayling RD, Bisgaard-Frantzen S, Adler A, Blowey RW, Barlow AM, Millar MF, van der Burgt GM, 2012 Detection of 'Candidatus mycoplasma haemobos', Mycoplasma wenyonii and Anaplasma phagocytophilum from cattle in England. Vet. Rec 170, 543.

Bourdoiseau G, 2006 Canine babesiosis in France. Vet. Parasitol 138, 118-125. [PubMed: 16507334]

de Caprariis D, Dantas-Torres F, Capelli G, Mencke N, Stanneck D, Breitschwerdt EB, Otranto D, 2011 Evolution of clinical, haematological and biochemical findings in young dogs naturally infected by vector-borne pathogens. Vet. Microbiol 149, 206-212. [PubMed: 21106311]

Ezeokoli CD, Ogunkoya AB, Abdullahi R, Tekdek LB, Sannusi A, Ilemobade AA, 1983 Clinical and epidemiological-studies on canine Hepatozoonosis in Zaria, Nigeria. J. Small Anim. Pract 24, 455460.

Girotto A, Zangirolamo AF, Bogado ALG, Souza ASLE, da Silva GCF, Garcia JL, Boas LAV, Biondo AW, Vidotto O, 2012 Molecular detection and occurrence of 'Candidatus mycoplasma haemobos' in dairy cattle of southern Brazil. Rev. Bras. Parasitol V 21, 342-344.

Gotsch S, Leschnik M, Duscher G, Burgstaller JP, Wille-Piazzai W, Joachim A, 2009 Ticks and haemoparasites of dogs from Praia, Cape Verde. Vet. Parasitol 166, 171-174. [PubMed: 19729247] 
Happi AN, Anita RE, 2012 Infection of dogs with Hepatozoon canis and other haemoprotozoan parasites in Ibadan, Nigeria. Trop. Vet 30, 178-187.

Harvey JW, 2001 Atlas of Veerinary Hematlogy: Blood and Bone Marrow of Domestic Animals W.B. Saunders Company.

Hii SF, Kopp SR, Thompson MF, O’Leary CA, Rees RL, Traub RJ, 2012 Canine vector-borne disease pathogens in dogs from south-east Queensland and north-east Northern Territory. Aust. Vet. J 90, 130-135. [PubMed: 22443327]

Hoelzle K, Winkler M, Kramer MM, Wittenbrink MM, Dieckmann SM, Hoelzle LE, 2011 Detection of Candidatus mycoplasma haemobos in cattle with anaemia. Vet. J 187, 408-410. [PubMed: 20188610]

Irwin PJ, 2009 Canine babesiosis: from molecular taxonomy to control. Parasit. Vectors 2 (Suppl. 1), S4.

Jain NC, 1986 Schalm's Veterinary Haematology, 4th edition. Lea and Febiger, Philadelphia.

Jensen WA, Lappin MR, Kamkar S, Reagan WJ, 2001 Use of a polymerase chain reaction assay to detect and differentiate two strains of Haemobartonella felis in naturally infected cats. Am. J. Vet. Res 62, 604-608. [PubMed: 11327472]

Kamani J, Baneth G, Mumcuoglu KY, Waziri NE, Eyal O, Guthmann Y, Harrus S, 2013 Molecular detection and characterization of tick-borne pathogens in dogs and ticks from Nigeria. PLoS Negl. Trop. Dis 7, e2108. [PubMed: 23505591]

Konto M, Biu AA, Ahmed MI, Charles S, 2014 Prevalence and seasonal abundance of ticks on dogs and the role of Rhipicephalus sanguineus in transmitting Babesia species in Maidugiri, northeastern Nigeria. Vet. World 7, 119-124.

Lappin MR, Breitschwerdt EB, Jensen WA, Dunnigan B, Rha JY, Williams CR, Brewer M, Fall M, 2004 Molecular and serologic evidence of Anaplasma phagocytophilum infection in cats in North America. J. Am. Vet. Med. Assoc 225 (893-896), 879.

Maggi RG, Compton SM, Trull CL, Mascarelli PE, Mozayeni BR, Breitschwerdt EB, 2013 Infection with hemotropic Mycoplasma species in patients with or without extensive arthropod or animal contact. J. Clin. Microbiol 51, 3237-3241. [PubMed: 23863574]

McFadden A, Ha HJ, Donald JJ, Bueno IM, van Andel M, Thompson JC, Tisdall DJ, Pulford DJ, 2016 Investigation of bovine haemoplasmas and their association with anaemia in New Zealand cattle. N. Z. Vet. J 64, 65-68. [PubMed: 26411673]

Meli ML, Willi B, Dreher UM, Cattori V, Knubben-Schweizer G, Nuss K, Braun U, Lutz H, HofmannLehmann R, 2010 Identification, molecular characterization, and occurrence of two bovine Hemoplasma species in Swiss cattle and development of real-time TaqMan quantitative PCR assays for diagnosis of bovine hemoplasma infections. J. Clin. Microbiol 48, 3563-3568. [PubMed: 20686093]

Nalubamba KS, Mudenda NB, Namwila MM, Mulenga CS, Bwalya EC, Kandawire EM, Saasa N, Hancanga C, Oparaocha E, Simuunza M, 2015 A study of naturally acquired canine babesiosis caused by single and mixed Babesia species in Zambia: clinicopathological findings and case management. J. Parasitol. Res 9, 236-249.

Nwoha RIO, Daniel-Igwe G, Onuekwusi GC, Onyeabor A, Igwe KC, Okah U, 2013 Incidences of Haemoparasites in dogs in Ikwuano local government area of Abia state. J. Vet. Sci. \& Technol 4, 141.

Ogo NI, de Mera IG, Galindo RC, Okubanjo OO, Inuwa HM, Agbede RI, Torina A, Alongi A, Vicente J, Gortazar C, de la Fuente J, 2012 Molecular identification of tick-borne pathogens in Nigerian ticks. Vet. Parasitol 187, 572-577. [PubMed: 22326937]

Okeke JJ, Ikegbunam NM, Umeaniebue AC, Ezeonyejiaku DC, Ezeadila JO, 2013 A survey on the Ectoparasites and Haemoparasites of Grasscutter (Thryonomys Swinderianus) reared under captive conditions. J. Nat. Sci. Res 3, 57-60.

Okubanjo OO, Adeshina OA, Jatau ID, Natala AJ, 2013 Prevalence of Babesia canis and Hepatozoon canis in Zaria, Nigeria. Sokoto J. Vet. Sci 11, 15-20.

Otranto D, Dantas-Torres F, Breitschwerdt EB, 2009 Managing canine vector-borne diseases of zoonotic concern: part two. Trends Parasitol 25, 228-235. [PubMed: 19346164] 
Penzhorn BL, 2011 Why is Southern African canine babesiosis so virulent? An evolutionary perspective. Parasit. Vectors 4, 51. [PubMed: 21489239]

Sasaki M, Omobowale O, Ohta K, Tozuka M, Matsuu A, Hirata H, Nottidge HO, Ikadai H, Oyamada T, 2008 A PCR-based epidemiological survey of Hepatozoon canis in dogs in Nigeria. J. Vet. Med. Sci 70, 743-745. [PubMed: 18685252]

Schalm OW, Jain NC, Carrol EJ, 1975 Veterinary Haematology 3rd Edition lea and Febiger (Philadephia).

Sikorski LE, Birkenheuer AJ, Holowaychuk MK, McCleary-Wheeler AL, Davis JM, Littman MP, 2010 Babesiosis caused by a large Babesia species in 7 immunocompromised dogs. J. Vet. Intern. Med 24, 127-131. [PubMed: 20002547]

Solano-Gallego L, Trotta M, Carli E, Carcy B, Caldin M, Furlanello T, 2008 Babesia canis canis and Babesia canis vogeli clinicopathological findings and DNA detection by means of PCR-RFLP in blood from Italian dogs suspected of tick-borne disease. Vet. Parasitol 157, 211-221. [PubMed: 18789581]

Suksawat J, Xuejie Y, Hancock SI, Hegarty BC, Nilkumhang P, Breitschwerdt EB, 2001 Serologic and molecular evidence of coinfection with multiple vector-borne pathogens in dogs from Thailand. J. Vet. Intern. Med 15, 453-462. [PubMed: 11596732]

Sykes JE, Ball LM, Bailiff NL, Fry MM, 2005 Candidatus mycoplasma haematoparvum', a novel small haemotropic mycoplasma from a dog. Int. J. Syst. Evol. Microbiol 55, 27-30. [PubMed: 15653848]

Tagawa M, Matsumoto K, Inokuma H, 2008 Molecular detection of mycoplasma wenyonii and 'Candidatus mycoplasma haemobos' in cattle in Hokkaido, Japan. Vet. Microbiol 132, 177-180. [PubMed: 18571343]

Tono RR, Faleke OO, Magaji AA, Alayande MO, Fajinmi AO, Ibitoye EB, 2015 Presence of Trypanosome Species and anemic status of dogs in Zuru. Nigeria Maced. Vet. Rev 38, 217-222.

Tsegay AK, Abebe B, Amano F, Gemeda, 2016 A Study on Prevalence of Major Tick and Tick Borne Hemoparasites of Dogs Visiting Jimma University Veterinary Open Air Clinic Middle-East. J. Sci. Res 24, 2342-2351.

Useh NM, Oladele SB, Adamu S, Ibrahim ND, Nok AJ, Esievo KA, 2003 Aetiology and prevalence of canine anaemia in Zaria: a review of 2139 cases observed at the veterinary teaching Hospital of the Ahmadu Bello University, Zaria, Nigeria (1990-2003). Vet Q 25, 150-154. [PubMed: 14714737]

Zahler M, Schein E, Rinder H, Gothe R, 1998 Characteristic genotypes discriminate between Babesia canis isolates of differing vector specificity and pathogenicity to dogs. Parasitol. Res 84, 544-548. [PubMed: 9694369] 

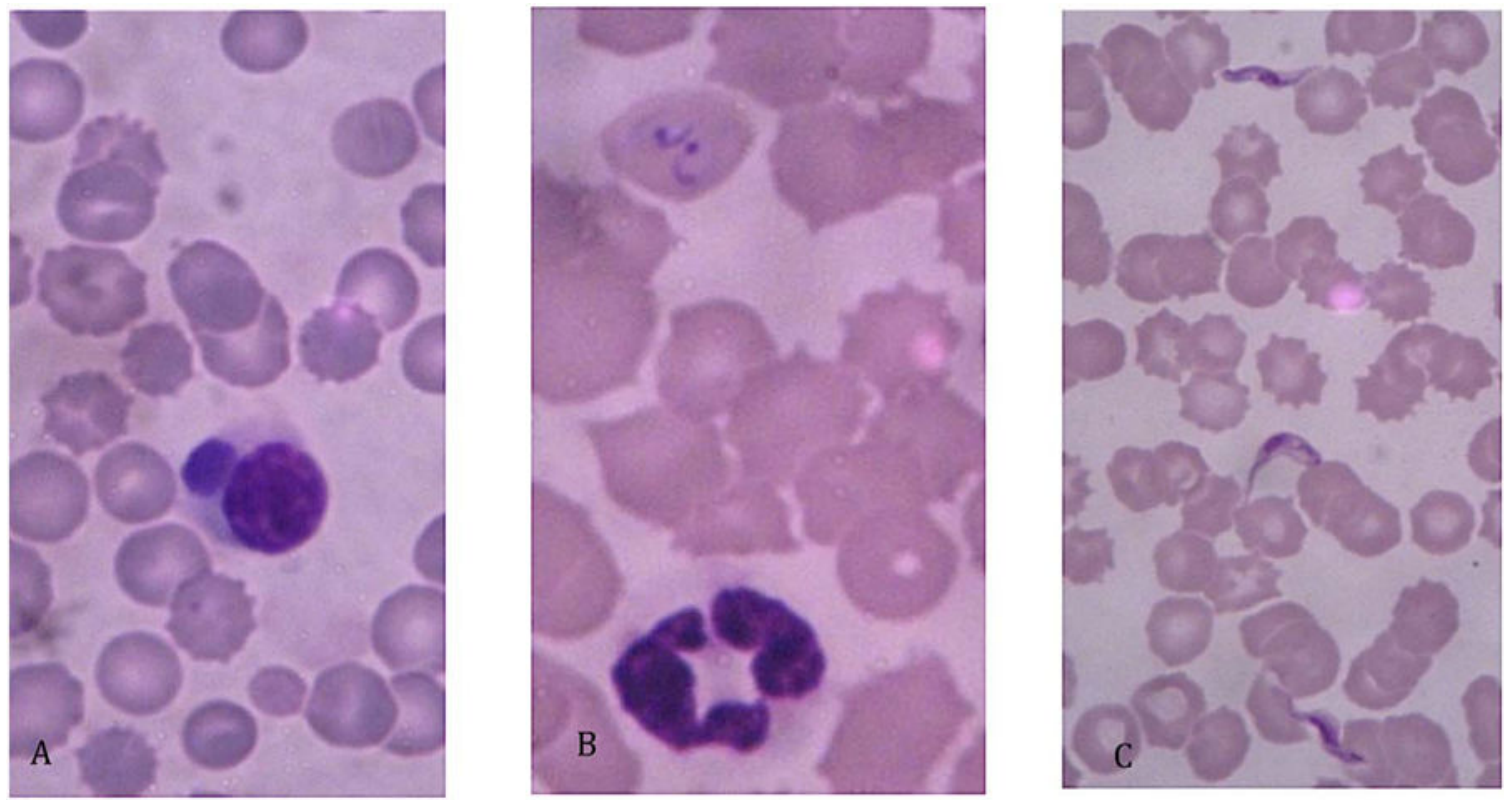

Fig. 1.

Dog blood smears showing Ehrlichia spp., Babesia spp., and Trypanosoma congolense. Ehrlichia spp. morulae in a lymphocyte (A), Babesia spp. in a red cell (B) and Trypanosoma congolense (C) (Giemsa stain; $\times 100$ objective). (For interpretation of the references to colour in this figure legend, the reader is referred to the web version of this article.) 


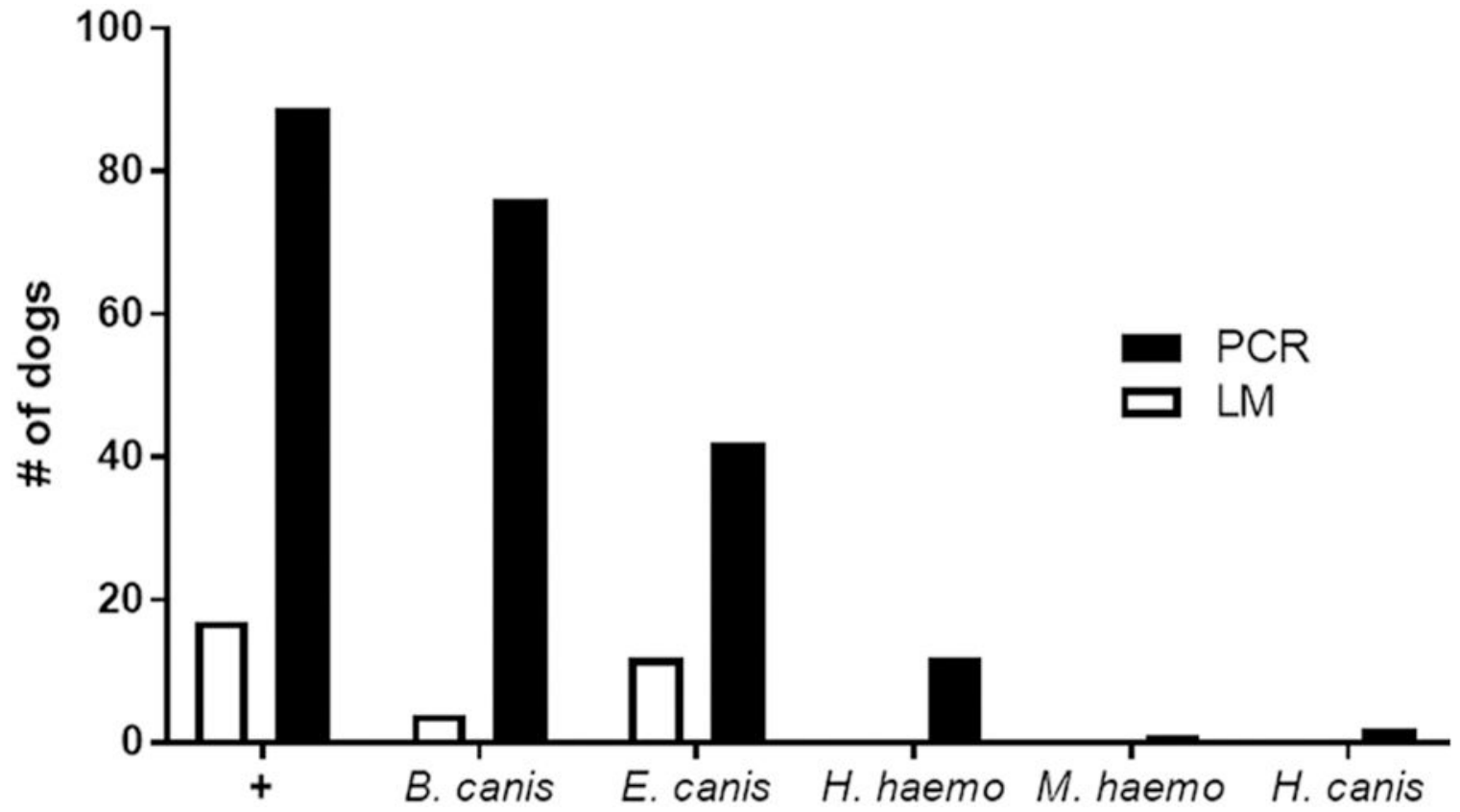

Fig. 2.

Comparison of LM and molecular diagnoses of blood-borne pathogen infection in dogs from UIVTH. Graphical representation of the number of dogs testing positive via light microscopy (LM) and polymerase chain reaction (PCR) for the following infections:

Babesia canis, Ehrlichia canis, Mycoplasma haemocanis, 'Ca. Mycoplasma haemobos', and Hepatozoon canis. 


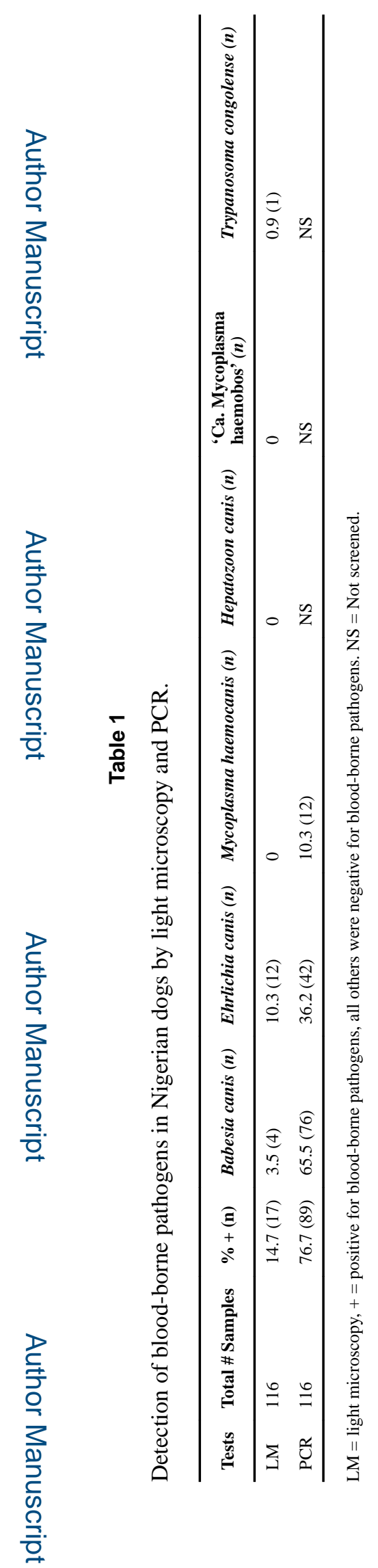

Vet Parasitol Reg Stud Reports. Author manuscript; available in PMC 2019 May 21. 
Table 2

Co-infection in Nigerian dogs with blood-borne pathogens.

\begin{tabular}{lll}
\hline Number of Pathogens & Number infected (\% per group of infection) & Percentage of all infected dogs (n= 89) \\
\hline Single infections $(\mathrm{n}=49 ; 55.1 \%)$ & & $41.6 \%$ \\
Babesia canis & $37(75.5 \%)$ & $10.1 . \%$ \\
Ehrlichia canis & $9(18.4 \%)$ & $3.4 \%$ \\
Mycoplasma haemocanis & $3(6.1 \%)$ & \\
Double infections $(\mathrm{n}=36 ; 40.4 \%)$ & & $32.5 \%$ \\
B. canis + E. canis & $29(80.6 \%)$ & $4.7 \%$ \\
B. canis + M. haemocanis & $4(11.1 \%)$ & $1.1 \%$ \\
B. canis + H. canis & $1(2.8 \%)$ & $1.1 \%$ \\
E. canis + M. haemobos & $1(2.8 \%)$ & $1.1 \%$ \\
B. canis + T. congolense & $1(2.8 \%)$ & \\
Triple infections $(\mathrm{n}=4 ;$ 4.5\%) & & $3.4 \%$ \\
B. canis + E. canis + M. haemocanis & $3(75.0 \%)$ & $1.1 \%$ \\
B. canis + M. haemocanis + H. canis & $1(25.0 \%)$ & \\
Total animals infected & 89 & \\
\hline
\end{tabular}


Happi et al.

Page 15

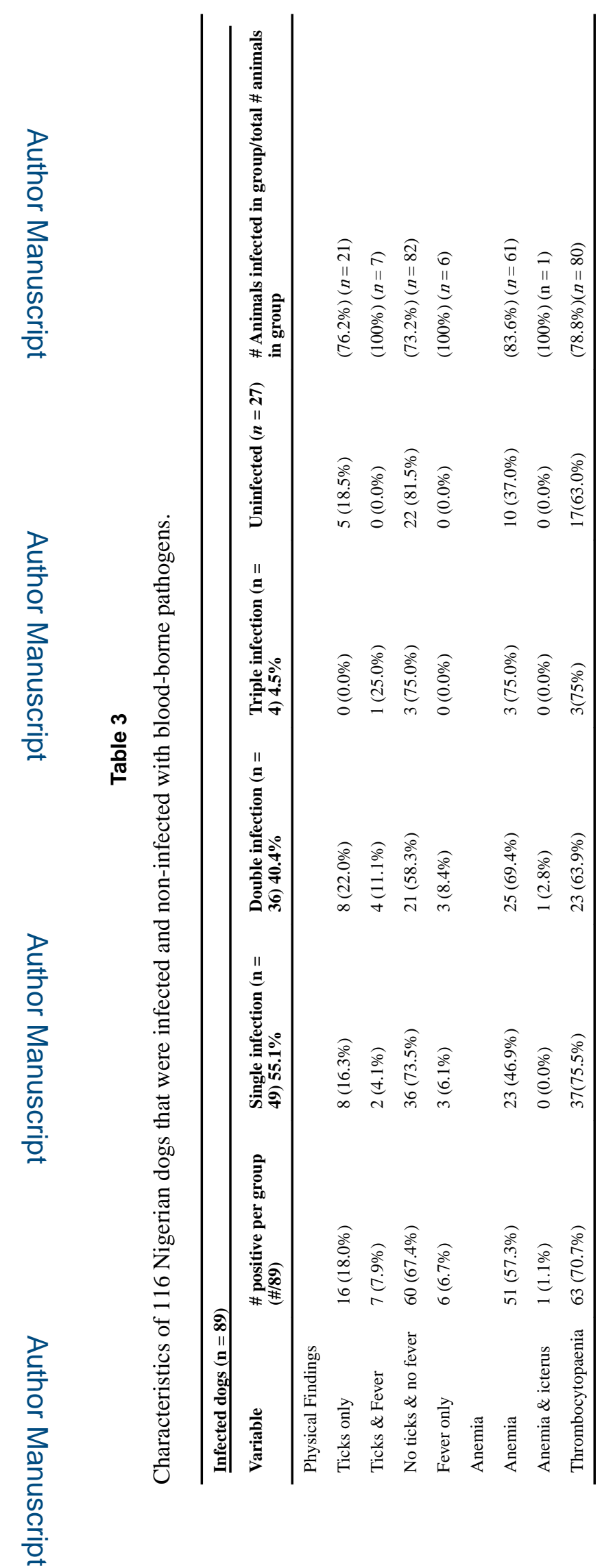

Vet Parasitol Reg Stud Reports. Author manuscript; available in PMC 2019 May 21. 


\section{Table 4}

Hematological abnormalities in dogs with single infections with blood-borne pathogens *

\begin{tabular}{llll}
\hline Variable & Babesia canis $(\mathrm{n}=37)$ & Ehrlichia canis $(\mathrm{n}=9)$ & Mycoplasma haemocanis $(\mathrm{n}=3)$ \\
\hline Anemia $(\mathrm{n}=23)$ & $16(43.2 \%)$ & $6(66.7 \%)$ & $1(33.3 \%)$ \\
Thrombocytopenia $(\mathrm{n}=37)$ & $30(81.1 \%)$ & $5(55.6 \%)$ & $2(66.7 \%)$ \\
Panleucopenia $(\mathrm{n}=13)$ & $10(27.0 \%)$ & $3(33.3 \%)$ & 0 \\
Pancytopenia $(\mathrm{n}=1)$ & 0 & $1(11.1 \%)$ & 0 \\
Neutropenia $(\mathrm{n}=15)$ & $12(32.4 \%)$ & $3(33.3 \%)$ & 0 \\
Leucopenia $(\mathrm{n}=19)$ & $14(37.8 \%)$ & $5(55.6 \%)$ & 0 \\
Leucocytosis $(\mathrm{n}=2)$ & $1(2.7 \%)$ & $1(11.1 \%)$ & 0 \\
\hline
\end{tabular}

* The hematology reference intervals used for the abnormal findings of these dogs are from Duncan and Prasse's Veterinary Laboratory MedicineClinical Pathology, Fifth Edition. 2011. 
Table 5

Variables associated with infection by blood-borne pathogens in Nigerian dogs.

\begin{tabular}{lllll}
\hline Pathogen & Variables & Odds Ratio & P-Value & 95\% CI \\
\hline Babesia spp. & No significant variables & & & \\
Ehrlichia spp. & Anemia & 2.77 & 0.01 & $1.25-6.16$ \\
Mycoplasma spp. & Presence of ticks & 3.73 & 0.04 & $1.10-12.70$ \\
\hline
\end{tabular}

